TITLE:

\title{
Bleaching of leaf litter and associated microfungi in subboreal and subalpine forests.
}

\section{AUTHOR(S):}

Hagiwara, Yusuke; Matsuoka, Shunsuke; Hobara, Satoru; Mori, Akira S; Hirose, Dai; Osono, Takashi

\section{CITATION:}

Hagiwara, Yusuke ... [et al]. Bleaching of leaf litter and associated microfungi in subboreal and subalpine forests.. Canadian journal of microbiology 2015, 61(10): 735-743

\section{ISSUE DATE:}

2015-10

URL:

http://hdl.handle.net/2433/202572

\section{RIGHT:}

This is the accepted manuscript (post-print) of an article is available at http://dx.doi.org/10.1139/cjm-2015-0111.; この論文は出版社版でありません。引用の際 には出版社版をご確認ご利用ください。; This is not the published version. Please cite only the published version. 
1 Bleaching of leaf litter and associated microfungi in subboreal and subalpine

2 forests

3

4 Yusuke Hagiwara, Shunsuke Matsuoka, Satoru Hobara, Akira S. Mori, Dai

$5 \quad$ Hirose, and Takashi Osono

6

7 Y. Hagiwara, S. Matsuoka, T. Osono. Center for Ecological Research, Kyoto

8 University, Otsu, Shiga 520-2113, Japan

9 S. Hobara. Department of Environmental Symbiotic Sciences, Rakuno Gakuen

10 University, Ebetsu, Hokkaido 069-8501, Japan

11 A. S. Mori. Graduate School of Environment and Information Sciences,

12 Yokohama National University, Yokohama, Kanagawa 204-8501, Japan

13 D. Hirose. College of Pharmacy, Nihon University, Funabashi, Chiba 274-8555,

14 Japan

15

16 Corresponding author: Takashi Osono (e-mail: tosono@ecology.kyoto-u.ac.jp) 
18 Abstract: Fungal decomposition of lignin leads to the whitening, or bleaching, of

19 leaf litter, especially in temperate and tropical forests, but less is known about such bleaching in forests of cooler regions, such as boreal and subalpine forests.

21 The purposes of the present study were to examine the extent of bleached area on the surface of leaf litter and its variation with environmental conditions in

23 subboreal and subalpine forests in Japan and microfungi associated with the

24 bleaching of leaf litter by isolating fungi from the bleached portions of the litter.

25 Bleached area accounted for $21.7 \%$ to $32.7 \%$ and $2.0 \%$ to $10.0 \%$ of total leaf area

26 of $Q$. crispula and B. ermanii, respectively, in subboreal forests, and for $6.3 \%$ and

$2718.6 \%$ of total leaf area of $B$. ermanii and $P$. jezoensis var. hondoensis,

28 respectively, in a subalpine forest. In subboreal forests, elevation, $\mathrm{C} / \mathrm{N}$ ratio and

$29 \mathrm{pH}$ of $\mathrm{FH}$ layer, and slope aspect were selected as predictor variables for the

30 bleached leaf area. Leaf mass per area and lignin content were consistently

31 lower in the bleached area than in the nonbleached area of the same leaves,

32 indicating that the selective decomposition of acid unhydrolyzable residue (AUR, 
33 recalcitrant compounds such as lignin, tannins, and cutins) enhanced the mass

34 loss of leaf tissues in the bleached portions. Isolates of a total of 11 fungal

35 species (six species of Ascomycota and five of Basidiomycota) exhibited

36 leaf-litter-bleaching activity under pure culture conditions. Two fungal species

37 (Coccomyces sp. and Mycena sp.) occurred in both subboreal and subalpine

38 forests which were separated from each other by approximately $1100 \mathrm{~km}$.

39

40 Key words: decomposition, elevational gradient, fungal diversity, leaves, lignin,

41 ligninolytic fungi.

42

43 Introduction

44

45

Fungi play central roles in the decomposition of lignin and other

46 recalcitrant compounds (often registered as acid unhydrolyzable residues) in

47 leaf litter of forest trees (van der Wal et al. 2013). Fungal decomposition of lignin

48 is mediated by the activity of such extracellular enzymes as lignin peroxidases, 
manganese peroxidases, phenol oxidases, and laccases (Eriksson et al. 1990) and

50 often leads to the whitening, or bleaching, of leaf litter (Osono 2007). The fungal

51 bleaching of leaf litter has been reported mainly from temperate and tropical

52 forests (Osono 2006; Osono et al. 2008a, 2009), and less is known about it in

53 forests of cooler regions, such as boreal and subalpine forests. The report of

54 Hintikka (1970) is one of the milestone papers about the diversity and

55 functioning of macrofungi (mainly in the Basidiomycota) associated with the

56 bleaching of forest litter in Finnish boreal forests. More recently, Miyamoto et al.

57 (2000) and Osono (2015c) showed that a suite of macrofungi in the

58 Basidiomycota were capable of actively decomposing lignin and bleaching leaf

59 litter in subboreal and subalpine forests of Japan. Compared to information

60 about macrofungi, however, information is still lacking in boreal and subalpine

61 forests regarding microfungi associated with the bleaching of leaf litter (Osono

62 2011) and possible climatic and environmental factors affecting their

63 abundance. 
65 bleached area on the surface of leaf litter and its variation with environmental

66 conditions and geographic locations and (ii) microfungi associated with the

67 bleaching of leaf litter by isolating fungi from the bleached portions as well as

68 surrounding nonbleached portions of the litter. We selected two study sites, one

69 in subboreal forest in northern Japan and another in subalpine forest in central

70 Japan, separated by $1100 \mathrm{~km}$ from each other, but having similar climatic

71 conditions and vegetation. Special attention was paid to an elevational gradient

72 on a mountain slope in the subboreal forest, in which sampling was conducted at

73 five elevational classes from $200 \mathrm{~m}$ to $1000 \mathrm{~m}$. Several environmental factors

74 were measured at sampling sites of different elevational classes to test the

75 relative importance of these factors affecting bleaching on leaf litter. Fungi were

76 isolated from bleached areas, as well as nonbleached areas, and were then

77 tested for their bleaching activity under a pure culture condition, and subjected

78 to DNA base sequence analysis for taxonomic identity and assignment. 


\section{Study sites}

84 Hokkaido and a subalpine forest in Gifu. The subboreal forests were located on

85 the northwest slope of Mt. Rausu $\left(44^{\circ} 04^{\prime} \mathrm{N}, 145^{\circ} 07^{\prime} \mathrm{E}\right)$ in Shiretoko Peninsula,

86 northeastern Japan. Mean annual temperature is $6.2{ }^{\circ} \mathrm{C}$, and mean annual

87 precipitation is $1090 \mathrm{~mm}$ at Utoro Station of Automatic Meteorological Data

88 Acquisition System of Japan Meteorological Agency, located $3 \mathrm{~m}$ above sea level

89 and $10 \mathrm{~km}$ southwest of the study site. Dominant trees in the plots included

90 Abies sachaliensis F.Schmidt, Quercus crispula Bl., Betula platyphylla Suk.,

91 and B. ermanii Cham. (Mori et al. in press). Bleaching was noticeable on leaf

92 litter of such tree species as Q. crispula, B. ermanii, Kalopanax pictus (Thunb.)

93 Nakai, Tilia maximowicziana Shirasawa, Acer japonicum Thunb., and $A$.

94 sachaliensis. In 2010, 10 study plots $(10 \mathrm{~m} \times 10 \mathrm{~m})$ each were established at 200,

$95400,600,800$, and $1000 \mathrm{~m}$ above sea level, making a total of 50 plots (Mori et al.

96 in press), and used for the collection of leaf litter. The maximum distance 
97 between the plots at each elevational class ranged between 311 and $435 \mathrm{~m}$.

98 Further details of the study site were described in Ikeda et al. (2014).

99

The subalpine forest was located on the north slope of Mt. Ontake,

100 central Japan (35 $56^{\prime} \mathrm{N}, 137^{\circ} 28^{\prime} \mathrm{E}, 2050 \mathrm{~m}$ above sea level). Mean annual

101 temperature is approximately $2{ }^{\circ} \mathrm{C}$, and mean annual precipitation is

102 approximately $2500 \mathrm{~mm}$ (Osono 2015b). The study site contains mainly four

103 coniferous species [Abies mariesii Masters, A. veitchii Lindley, Picea jezoensis

104 var. hondoensis (Sieb. et Zucc.) Carrière, and Tsuga diversifolia (Maxim.)

105 Masters] and one hardwood species (B. ermanii). Bleaching was noticeable on

106 leaf litter of two tree species: $B$. ermanii and $P$. jezoensis var. hondoensis. A

107 study plot of $50 \mathrm{~m} \times 10 \mathrm{~m}$ was laid out in 2008 and used for the collection of leaf

108 litter. Further details of the study site were given in Osono and Takeda (2007).

\section{Collection of leaves}

112 of $Q$. crispula and B. ermanii of which more than half of the original leaf area 
113 remained were collected from the surface of the forest floor beneath the canopy

114 of the respective tree species using a $15 \mathrm{~cm} \times 15 \mathrm{~cm}$ quadrat. Leaves of $Q$.

115 crispula were present in 10 plots each of elevational classes 200,400 , and $600 \mathrm{~m}$,

116 but not in the plots of elevational class 800 or $1000 \mathrm{~m}$. Leaves of B. ermanii were

117 collected from 7, 4, 10, 10, and 10 plots of elevational classes 200, 400, 600, 800,

118 and $1000 \mathrm{~m}$, respectively. Additionally, 20 leaves each of $Q$. crispula and $B$.

119 ermanii with evident bleaching were arbitrarily collected from the plots at 400

$120 \mathrm{~m}$ and were used for fungal isolation.

123 of $B$. ermanii of which more than half of the original leaf area remained, or

124 needles of $P$. jezoensis var. hondoensis were collected from the surface of the

125 forest floor beneath the canopy of 10 individuals of each tree species using a 15

$126 \mathrm{~cm} \times 15 \mathrm{~cm}$ quadrat. Additionally, 20 leaves each of $B$. ermanii and $P$. jezoensis

127 var. hondoensis with evident bleaching were arbitrarily collected from the plot

128 and were used for fungal isolation. Trees are referred to by their genus names in 
129 the present study for the sake of simplicity.

130

131 Measurement of leaves

132

The leaves for leaf area measurement were placed in paper bags and

133 taken back to the laboratory at ambient temperature. The leaves of Quercus and

134 Betula were pressed between layers of plywood and paper and oven-dried at

$13540{ }^{\circ} \mathrm{C}$ for one week. The leaves were then photocopied and scanned with a

136 photoscanner (EPSON GT-8000). Total leaf area and the proportion of bleached

137 area were measured with an image software (NIH image, Windows version

138 v.4.0.3, Scion), according to the method described in Hagiwara et al. (2012). Ten

139 Picea needles were randomly selected for each quadrat, oven-dried at $40{ }^{\circ} \mathrm{C}$ for

140 one week, and measured for total length and the length of needle portions with

141 bleaching under a binocular microscope with magnification of $40 \times$ (Hirose and

142 Osono 2006). The bleached area or bleached length of leaves was defined as the

143 bleached percentage of the total leaf area or length. The bleached length of Picea

144 needles was denoted here as the bleached area for the sake of simplicity. The 
mean value of the bleached area was calculated for each elevational class in

146 subboreal forests and for the plot in the subalpine forest.

148 primary vein, from the bleached area and surrounding nonbleached area of the

149 same leaves of $Q$. crispula and B. ermanii from subboreal and subalpine forests.

150 Three to 61 disks (mean: 11 disks) were punched out for each quadrat. The disks

151 were oven-dried again at $40{ }^{\circ} \mathrm{C}$ for one week and weighed to calculate leaf mass

152 per area (LMA). To compare the chemical composition, the disks were combined

153 to make one sample each of bleached and nonbleached leaf area for each tree

154 species and each study site, ground in a laboratory mill, and used for proximate

155 chemical analyses. Content of acid unhydrolyzable residue (AUR) was measured

156 with hot sulfuric acid digestion, according to the method described in Osono

157 (2015c).

We measured five environmental variables for each study plot of

159 subboreal forests that were expected to influence the occurrence of bleached

160 portions on leaves: carbon to nitrogen $(\mathrm{C} / \mathrm{N})$ ratio, $\mathrm{pH}(\mathrm{KCl})$, and gravimetric 
161 water content of all materials in FH layer, inclination of the slope, and the slope

162 aspect. Methods of measurement of these variables were described in Mori et al.

163 (in press). Briefly, total carbon and nitrogen contents were determined with

164 combustion method by automatic gas chromatography (NC analyzer

165 SUMIGRAPH NC-900, Sumitomo Chemical, Osaka, Japan). The pH was

166 measured in a $1 \mathrm{~N}$ potassium chloride solution with Docu-pH meter+ (Sartorius,

167 Goettingen, Germany)

168

169 Isolation and screening of bleaching fungi

The leaves for fungal isolation were placed in paper bags and preserved

171 at $4{ }^{\circ} \mathrm{C}$ for no longer than three days before the isolation of fungi. Single leaf

172 disks were excised from the bleached portion of individual leaves of Quercus and

173 Betula, using a sterile 6-mm-diameter cork borer, and other single disks were

174 excised from the nonbleached portion of the same leaves. One bleached and one

175 nonbleached portion (5-10 $\mathrm{mm}$ in length) were cut separately and aseptically for

176 individual Picea needles. This produced a total of 20 bleached and 20 
177 nonbleached disks or needle portions for each tree species from each study site.

178 Fungi were isolated from bleached and nonbleached disks or needle portions

179 using the surface disinfection method according to Hirose et al. (2014). The

180 surface-disinfected materials were plated on $9-\mathrm{cm}$ Petri dishes containing $2 \%$

181 lignocellulose agar (LCA) modified as described by Miura and Kudo (1970)

182 [glucose $0.1 \%, \mathrm{KH}_{2} \mathrm{PO}_{4} 0.1 \%, \mathrm{MgSO}_{4} \cdot 7 \mathrm{H}_{2} \mathrm{O} 0.02 \%, \mathrm{KCl} 0.02 \%, \mathrm{NaNO}_{3} 0.2 \%$,

183 yeast extract $0.02 \%$, and agar $2 \%(\mathrm{w} / \mathrm{v})$ ], two disks or needle portions per plate.

184 Note that the modified LCA of Miura and Kudo (1970) does not contain lignin or

185 other recalcitrant compounds. The modified LCA was used because its low

186 glucose content suppresses the overgrowth of fast-growing fungal species (Osono

187 and Takeda 1999). The plates were incubated in darkness at $10^{\circ} \mathrm{C}$ and observed

188 for 4 weeks after the disinfection. Any fungal hyphae or spores appearing on the

189 plates were subcultured onto fresh LCA plates, incubated, and observed

190 micromorphologically.

192 culture condition. Newly shed leaves of Quercus and Betula without obvious 
193 fungal or faunal attack were collected from the forest floor of subboreal forests

194 in July 2010, and those of Betula were collected from the subalpine forest in

195 September 2008. These leaves were oven-dried at $40^{\circ} \mathrm{C}$ for one week, cut into

196 pieces $(1 \mathrm{~cm} \times 1 \mathrm{~cm})$, and autoclaved at $120^{\circ} \mathrm{C}$ for $20 \mathrm{~min}$. The sterilized leaf

197 pieces were placed on the surface of Petri dishes (6 $\mathrm{cm}$ diameter), one piece per

198 plate, containing $20 \mathrm{ml}$ of $2 \%$ malt extract agar [malt extract $2 \%$ and agar $2 \%$

$199(\mathrm{w} / \mathrm{v})]$ previously inoculated with fungal isolates and incubated at $20^{\circ} \mathrm{C}$ for two

200 weeks. Quercus isolates were inoculated with sterilized Quercus leaf pieces, and

201 Betula and Picea isolates were inoculated with Betula leaf pieces. The plates

202 were sealed firmly with laboratory film so that moisture did not limit the

203 bleaching on the agar medium and incubated at $20^{\circ} \mathrm{C}$ for 24 weeks in the dark.

204 After incubation, the leaf pieces were retrieved and examined under a binocular

205 microscope with magnification of $40 \times$ for the occurrence of bleaching on the leaf

206 surface. The occurrence of bleaching was scored visually into six classes: 0, no

207 bleached portion; 1 , bleached in $1 \%$ to $20 \%$ of leaf area; 2 , bleached in $21 \%$ to

$20840 \% ; 3$, bleached in $41 \%$ to $60 \%$; 4 , bleached in $61 \%$ to $80 \%$; and 5 , bleached in 
$20981 \%$ to $100 \%$. The visual class was tranformed into the percentage bleached area

210 with respect to the total leaf area by applying the median for each of class 1 to 5 .

211 Three control plates with the sterilized leaves but no fungal inoculation were

212 also incubated under the same conditions. No microbial colonies or bleaching

213 developed on the control plates, indicating the effectiveness of the sterilization

214 method used in the present study. Fungal isolates with the score of 1 to 5 were

215 regarded as possessing bleaching activity. We obtained a total of 180 fungal

216 isolates from 160 leaf disks (four litter types $\times$ two portions $\times 20$ leaves), of

217 which 40 isolates were judged to be bleaching fungi and used for molecular

218 analysis as described below.

219

220 Molecular methods

Genomic DNA was extracted from mycelia that had been cultured on

2.5\% malt extract agar overlaid with a cellophane membrane following the

223 modified CTAB method described by Matsuda and Hijii (1999). Polymerase

224 chain reaction (PCR) was performed using a Quick Taq HS DyeMix (Toyobo, 
225 Osaka, Japan). Each PCR reaction contained a $50 \mu$ l mixture [21 $\mu$ l distilled 226 water, $25 \mu \mathrm{l}$ master mix, $3 \mu \mathrm{l}$ ca. $0.5 \mathrm{ng} / \mu \mathrm{l}$ template DNA, and $0.5 \mu \mathrm{l}$ of each 227 primer (final, $0.25 \mu \mathrm{M}$ )]. To PCR amplify the region including the rDNA ITS and 228 28S rDNA D1-D2 domain, the primer pair ITS1f (Gardes and Bruns 1993) and 229 LR3 (Vilgalys and Hester 1990) was used. Each DNA fragment was amplified 230 using a PCR thermal cycler (DNA engine; Bio-Rad, Hercules, CA, USA) using 231 the following thermal cycling schedule. The first cycle consisted of 5 min at $94^{\circ} \mathrm{C}$, 232 followed by 35 cycles of $30 \mathrm{~s}$ at $94^{\circ} \mathrm{C}, 30 \mathrm{~s}$ at $50^{\circ} \mathrm{C}$ for annealing, $1 \mathrm{~min}$ at $72^{\circ} \mathrm{C}$, 233 and a final cycle of $10 \mathrm{~min}$ at $72^{\circ} \mathrm{C}$. The reaction mixture was then cooled at $4^{\circ} \mathrm{C}$ 234 for 5 min. PCR products were purified with a QIAquick PCR Purification Kit 235 (Qiagen, Germany) according to the manufacturer's instructions. Purified PCR products were sequenced by FASMAC Co., Ltd.

237 (Kanagawa, Japan). Sequencing reactions were performed in a Gene Amp PCR 238 System 9700 (Applied Biosystems, USA) using a BigDye Terminator V3.1 239 (Applied Biosystems), following the protocols supplied by the manufacturer. The 240 fluorescent-labeled fragments were purified from the unincorporated 
241 terminators using an ethanol precipitation protocol. The samples were

242 resuspended in formamide and subjected to electrophoresis in an ABI 3730xl

243 sequencer (Applied Biosystems).

The sequences determined in the present study were deposited in the

245 DNA Data Bank of Japan (DDBJ) (LC014885 to LC014897). The rDNA ITS and

$24628 \mathrm{~S}$ sequences were compared with available rDNA sequences in the GenBank

247 database using BLASTN searches (Altschul et al. 1990). For phylogenetic

248 analysis, MAFFT ver. 7 (Katoh and Standley 2013) was used for preliminary

249 multiple alignments of nucleotide sequences. Final alignments were manually

250 adjusted using BioEdit (Hall 1999). Alignment gaps were treated as missing

251 data, and ambiguous positions were excluded from the analysis. Phylogenetic

252 tree was conducted by Maximum Likelihood (ML) methods (Felsenstein 1981)

253 with the best fit nucleotide substitution model based on the lowest BIC score

254 (Bayesian Information Criterion). To estimate clade support, the bootstrap

255 procedure of Felsenstein (1985) was employed with 1000 replicates. These

256 analyses were carried out using MEGA6 (Tamura et al. 2013). 
258 operational taxonomic units according to the similarity of $28 \mathrm{~S}$ rDNA D1-D2

259 sequences with a criterion of $98 \%$. Based on the results of molecular barcoding

260 and micromorphological observation, we determined the identity and taxon of

261 fungal isolates with bleaching activity.

262

263 Statistical analysis

264

Generalized linear models (GLMs) were used to evaluate the difference

in bleached area of $B$. ermanii and $Q$. crispula leaf litter in subboreal forests

with a Gaussian distribution using the elevational class, $\mathrm{C} / \mathrm{N}$ ratio, $\mathrm{pH}$, and

268 predictor variables. The GLMs were performed with the $g l m$ function of $\mathrm{R}$

version 3.0.2 for Mac (http://www.r-project.org) and with the $g$ lht function of the

$270 \mathrm{R}$ multcomp package for multiple comparisons with Tukey's test. To find the

271 most parsimonious models we performed automatic forward stepwise model

272 selections with the Akaike information criterion (AIC), using the minimum AIC 
273 as the best-fit estimator. The model selections were performed with the stepAIC

274 function of R. The GLMs were used to evaluate the difference in LMA of $B$.

275 ermanii and Q. crispula leaf litter in subboreal forests with a Gaussian

276 distribution using the leaf portions (bleached vs nonbleached) and the

277 elevational class as predictor variables.

278

279 Results

280

281 Bleached area on leaf litter

Bleached area accounted for $21.7 \%$ to $32.7 \%$ and $2.0 \%$ to $10.0 \%$ of the

283 mean total leaf area of Q. crispula and B. ermanii, respectively, in subboreal

284 forests and for $6.3 \%$ and $18.6 \%$ of total leaf area of B. ermanii and P. jezoensis

285 var. hondoensis, respectively, in subalpine forest (Fig. 1a). In subboreal forests,

286 elevational class, $\mathrm{C} / \mathrm{N}$ ratio and $\mathrm{pH}$ of $\mathrm{FH}$ layer, and/or slope aspect were

287 selected as predictor variables for the bleached leaf area of $Q$. crispula and $B$.

288 ermanii, of which the elevational class and $\mathrm{C} / \mathrm{N}$ ratio of $\mathrm{FH}$ layer had significant 
$289 \chi^{2}$ values $(\mathrm{P}<0.05)$ for $Q$. crispula and the elevational class had a significant $\chi^{2}$

290 value $(\mathrm{P}<0.05)$ for $B$. ermanii (Table 1 , Fig. 1b). The bleached area on Q. crispula

291 leaves was significantly $(\mathrm{P}<0.05)$ greater at $600 \mathrm{~m}$ than at 200 and $400 \mathrm{~m}$, and

292 that on $B$. ermanii leaves was significantly $(\mathrm{P}<0.05)$ greater at $600 \mathrm{~m}$ than at

293800 and $1000 \mathrm{~m}$. The water content of FH layer and the inclination of the slope

294 were not selected as predictor variables for the bleached leaf area of $Q$. crispula

295 or B. ermanii.

296

Leaf mass per area (LMA) was consistently lower in the bleached area

297 than in the nonbleached area of the same leaves for $Q$. crispula and B. ermanii

298 from subboreal and subalpine forests (Table 2). The difference in LMA between

299 the bleached and nonbleached area was statistically significant (GLM, P<0.001)

300 for the two tree species from subboreal forests (Table 2). The LMA of $Q$. crispula

301 was also significantly (GLM, P<0.001) lower at the elevational classes of 400

302 and $600 \mathrm{~m}$ than at $200 \mathrm{~m}$ (Table 2). AUR content was lower in the bleached leaf

303 area than in the nonbleached leaf area for $Q$. crispula and $B$. ermanii from

304 subboreal forests (Table 2). 
305

\section{$306 \quad$ Fungi with bleaching activity}

307

A total of 11 fungal species (six in Ascomycota and five in

308 Basidiomycota) were isolated from bleached and/or nonbleached portions and

309 exhibited bleaching activity under pure culture conditions (Table 3, Fig. 2). Five

310 of the six ascomycete species belonged to Rhytismataceae and the other to

311 Xylariaceae; two basidiomycete species belonged to Tricholomataceae and the

312 others to Mycenaceae, Russulaceae, or Phanerochaetaceae (Fig. 2). The

313 bleaching activity was lower in Xylariaceae sp. (which caused mean bleaching of

314 less than $10 \%$ of the leaf area) than in rhytismataceous and basidiomycete

315 species (which causing bleaching of more than or equal to $50 \%$ of the leaf area)

316 (Table 3).

317 Three, three, five, and four fungal species were detected as fungi with

318 bleaching activity toward $Q$. crispula, B. ermanii of subboreal forest, $B$. ermanii

319 of subalpine forest, and $P$. jezoensis var. hondoensis, respectively (Table 3).

320 Coccomyces sp. and Mycena sp. occurred on leaves of three tree species in both 
321 subboreal and subapline forests (Table 3).

322

323 Discussion

324

325

The proportions of the bleached area of $Q$. crispula leaves were at the

326

highest part of the range previously reported for tree leaves in temperate and

327 tropical forests, whereas those of $B$. ermanii leaves were at the low to middle

328 part of the range (summarized in Osono 2006; Hagiwara et al. 2012). The higher

329 bleached area of $Q$. crispula leaves than in that of $B$. ermanii leaves was possibly

330 attributed to the lower content of AUR (Table 2) and nitrogen (discussed further

331 below) in $Q$. crispula leaves. Few data have been available on the bleached

332 portion of conifer needles comparable to the needles of $P$. jezoensis var.

333 hondoensis in the subalpine forest. The lower LMA and the lower AUR content

334 on the bleached area than on the nonbleached area are consistent with previous

335 data (Osono 2006) and indicate that the selective decomposition of AUR

336 enhanced the mass loss of leaf tissues in the bleached portions which 
337 ligninolytic fungi colonized, compared to the nonbleached portions of the same

338 leaves.

339

In subboreal forests, the proportions of the bleached area on leaves of

340 both $Q$. crispula and $B$. ermanii reached the highest value at the elevational

341 class of $600 \mathrm{~m}$, and that of $Q$. crispula was significantly affected by the $\mathrm{C} / \mathrm{N}$ ratio

342 of FH layer (Fig. 1, Table 1). These results suggested that the bleached area did

343 not respond linearly with the temperature lapse with the elevation and possible

344 effects of other local factors. For example, previous studies demonstrated

345 difference in microfungal assemblages at different elevational classes (van

346 Maanen et al. 2000; Gourbière et al. 2001; Osono and Hirose 2009b). There is

347 also some evidence to suggest that high $\mathrm{N}$ content could inhibit colonization by

348 ligninolytic fungi. For example, $\mathrm{N}$ could cause a biochemical suppression of

349 AUR-degrading enzymes of fungi (Keyser et al. 1978; Fenn et al. 1981). Osono et

350 al. (2002) reported that avian excreta rich in $\mathrm{N}$ suppressed the colonization of

351 litter by ligninolytic fungi. Similarly, Hagiwara et al. (2012) found that the

352 bleached area of Acacia mangium leaf litter was negatively correlated with $\mathrm{N}$ 
353 content of the litter, supporting the notion that the colonization of leaves by

354 ligninolytic fungi could be inhibited by higher $\mathrm{N}$ content. The unimodal pattern

355 of bleached area on B. ermanii leaves along the elevational gradient (Fig. 1a)

356 implied that not only $\mathrm{N}$ level, $\mathrm{pH}$, and the slope aspect but also other

357 microenvironmental factors, such as the composition of tree and ground

358 vegetation, singly or in combination, might affect the occurrence of bleached

359 area on the litter. Two other possible factors affecting the occurrence of bleached

360 portions on leaf litter along the elevational gradient include (i) different leaf fall

361 time between the study sites and (ii) competition between bleaching fungi and

362 other microbes.

363

The present results of proximate chemical composition analysis of leaf

364 tissues, the isolation of fungi, and the pure culture bleaching assay

365 demonstrated that 11 fungal species were responsible for AUR decomposition

366 and bleaching of leaf litter in the subboreal and subalpine forests. The

367 taxonomic composition of bleaching fungi of subboreal and subalpine leaves was

368 generally consistent with that reported for other temperate and tropical regions. 
369 Regarding Ascomycetes, species in the Rhytismataceae have been reported to

370 bleach the leaf litter and decompose the AUR fraction of Camellia japonica

371 (Koide et al. 2005b; Osono and Hirose 2009a), Gaultheria shallon (Osono et al.

372 2008b), and Pinus spp. (Osono and Hirose 2011). These rhytismataceous species

373 can be endophytic on live leaf tissues and take part in lignin decomposition in

374 early stages of decomposition (Koide et al. 2005a). Fungi in the Xylariaceae in

375 Ascomycetes are well known for their ligninolytic activity, especially in the

376 tropics (e.g. Osono et al. 2011, 2013). Basidiomycetes are major components of

377 ligninolytic fungal assemblages in temperate and tropical forests (Boddy et al.

378 2008; Osono 2015a). Mycena sp. isolated as a bleaching fungus in the present

379 study was also found fruited on the forest floor of the subalpine forest (Osono

380 2015a) and caused the selective delignification of Betula leaves (Osono 2015d).

381

The present study demonstrated the occurrence of bleaching on leaf

382 litter of subboreal and subalpine forests in Japan, and the association of fungi

383 with it. The occurrence of the same fungal species (Coccomyces sp. and Mycena

384 sp.) at the two locations, despite their distance of approximately $1100 \mathrm{~km}$ from 
385 each other, can be partly attributed to the similarity in the climatic conditions

386 and vegetation between these subboreal and subalpine forests. Similarly,

387 fruiting bodies of such ligninolytic macrofungi as $M$. aurantiidisca were

388 observed in both a subboreal forest in Hokkaido (Miyamoto et al. 1998) and the

389 subalpine forest of the present study (Osono 2015a). It remains unclear to what

390 extent the bleaching fungi contribute to the loss of AUR in decomposing litter on

391 the forest floor of these forest stands. Tian et al. (2000), for example, found that

392 the decomposition of AUR was slower than that of carbohydrates in leaf litter

393 during a 3.5-year incubation in subalpine forest, suggesting relatively minor

394 roles of ligninolytic activity compared to cellulolytic activity of the whole fungal

395 assemblages. Further studies will be needed to follow simultaneously the

396 changes in bleached area, the succession of ligninolytic fungi, and the loss of

397 AUR in decomposition processes to quantify the role of fungi associated with the

398 bleaching. 
401

402 This study was supported by the Ministry of Education, Culture, Sports, Science,

403 and Technology of Japan (MEXT) (No.19780114, No.15K07480), the Sumitomo

404 Foundation, and the Japan Securities Scholarship Foundation. The Shiretoko

405 Foundation provided logistical support for the fieldwork. We thank H. Kondo, K.

406 Koizumi, Y. Miyake, W. Azuma, H. Kamauchi, and N. Mori for their assistance.

407

408 References

409

410 Altschul, S.F., Gish, W., Miller, W., Myers, E.W., and Lipman, D.J. 1990. Basic

412 Boddy, L., Frankland, J.C., and van West, P. 2008. Ecology of Saprotrophic Basidiomycetes. Academic Press, London.

414 Eriksson, K.E., Blanchetter, R.A., and Ander, P. 1990. Microbial and enzymatic degradation of wood and wood components. Springer, New York.

416 Felsenstein, J. 1981. Evolutionary trees from DNA sequences: a maximum 
418 Felsenstein, J, 1985. Confidence limits on phylogenies: an approach using the bootstrap. Evolution 39: 783-791.

Fenn, P., Choi, S., and Kirk, T.K. 1981. Ligninolytic activity of Phanerochaete chrysosporium: Physiology of suppression by $\mathrm{NH}_{4}^{+}$and L-Glutamate. Microbiology 130: 66-71.

423 Gardes, M., and Bruns, T.D. 1993. ITS primers with enhanced specificity for basidiomycetes: application to the identification of mycorrhizae and rusts. Mol. Ecol. 21: 113-118.

Gourbière, F., van Maanen, A., and Debouzie, D. 2001. Associations between three fungi on pine needles and their variation along a climatic gradient. Mycol. Res. 105: 1101-1109. and decomposition of leaf litter by ligninolytic fungi in Acacia mangium plantations and adjacent secondary forests. J. For. Res. 17: 51-57.

432 Hall, TA, 1999. BioEdit: a user-friendly biological sequence alignment editor and 
Hintikka, V. 1970. Studies on white-rot humus formed by higher fungi in forest soils. Commun. Inst. For. Fenn. 69.2: 1-68.

437 Hirose, D., and Osono, T. 2006. Development and seasonal variation of Lophodermium populations on Pinus thunbergii needle litter. Mycoscience 47: 242-247. associated with withering willow wood in ground contact near Syowa Station, East Antarctica for 40 years. Polar Biol. 36: 919-924.

443 Ikeda, A., Matsuoka, S., Masuya, H., Mori, A.S., Hirose, D., and Osono, T. 2014. Comparison of the diversity, composition, and host recurrence of xylariaceous endophytes in subtropical, cool temperate, and subboreal regions in Japan. Popul. Ecol. 56: 289-300.

447 Katoh, K., Standley, D.M., 2013. MAFFT multiple sequence alignment software version 7: improvements in performance and usability. Mol. Biol. Evol. 
30: 772-780.

450 Keyser, P., Kirk, T.K., and Zeikus, J.G. 1978. Ligninolytic enzyme system of Phanerochaete chrysosporium: Synthesized in the absence of lignin in response to nitrogen starvation. J. Bacteriol. 135: 790-797.

453 Kimura, M., 1980. A simple method for estimating evolutionary rate of base substitutions through comparative studies of nucleotide sequences. J. Mol. Evol. 16: 111-120.

456 Koide, K., Osono, T., and Takeda, H. 2005a. Colonization and lignin decomposition of Camellia japonica leaf litter by endophytic fungi. Mycoscience 46: 280-286.

459 Koide, K., Osono, T., and Takeda, H. 2005b. Fungal succession and 460 decomposition of Camellia japonica leaf litter. Ecol. Res. 20: 599-609.

461 Matsuda, Y., and Hijii, N. 1999. Characterization and identification of 462 Strobilomyces confusus ectomycorrhizas on momi fir by RFLP analysis of the PCR-amplified ITS region of the rDNA. J. For. Res. 4: 145-150.

464 Miyamoto, T., Igarashi, T., and Takahashi, K. 1998. Notes on three species of 

337-342.

467 litter-decomposing basidiomycetes from Picea forests of Hokkaido. Mycoscience 41: 105-110.

Miura, K., and Kudo, M. 1970. An agar-medium for aquatic hyphomycetes. Trans. Mycol. Soc. Japan 11: 116-118. (in Japanese)

Mori, A.S., Shiono, T., Haraguchi, T., Ota, A., Koide, D., Ohgue, T., Kitagawa, R., Maeshiro, R., Aung, T.T., Nakamori, T., Hagiwara, Y., Matsuoka, S., Ikeda, A., Hishi, T., Hobara, S., Mizumachi, E., Frisch, A., Thor, G., Fujii, S., Osono, T., and Gustafsson, L. Functional redundancy of multiple forest taxa along an elevational gradient: predicting the consequences of non-random species loss. J. Biogeogr. in press. doi: 10.1111/jbi.12514

Osono, T. 2006. Fungal decomposition of lignin in leaf litter: comparison between tropical and temperate forests. In Proceedings for the 8th International Mycological Congress, August 20-25, 2006, Cairns, 

$111-117$

483 Osono, T. 2007. Ecology of ligninolytic fungi associated with leaf litter decomposition. Ecol. Res. 22: 955-974. decomposition in an Asian climatic gradient. Fungal Ecol. 4: 375-385. of litter-decomposing macrofungi in subtropical, temperate, and subalpine forests. J. For. Res. 20: 60-68.

Osono, T. 2015b. Hyphal length in the forest floor and soil of subtropical, temperate, and subalpine forests. J. For. Res. 20: 69-76. decomposition of leaf litter by macrofungi. J. For. Res. 20: 77-84.

494 Osono, T. 2015d. Decomposing ability of diverse litter-decomposer macrofungi in subtropical, temperate, and subalpine forests. J. For. Res. 20: in press. 
on leaf litter of Fagus crenata. Ap. For. Sci. Kansai 8: 103-108. (in

Japanese with English abstract)

Osono, T., and Takeda, H. 2007. Microfungi associated with Abies needles and Betula leaf litter in a subalpine coniferous forest. Can. J. Microbiol. 53:

501 $1-7$.

Osono, T., and Hirose, D. 2009a. Effects of prior decomposition of Camellia japonica leaf litter by an endophytic fungus on the subsequent decomposition by fungal colonizers. Mycoscience 50: 52-55.

Osono, T., and Hirose, D. 2009b. Altitudinal distribution of microfungi associated with Betula ermanii leaf litter on Mt. Rishiri, northern Japan. Can. J. Microbiol. 55: 783-789. needle litter by Lophodermium pinastri. Forest Pathol. 41: 156-162. 
514 Osono, T., Ishii, Y., and Hirose, D. 2008a. Fungal colonization and decomposition 909-917.

517 Osono, T., Iwamoto, S., and Trofymow, J.A. 2008b. Colonization and decomposition of salal (Gaultheria shallon) leaf litter by fungi in successional forests on coastal British Columbia. Can. J. Microbiol. 54: $427-434$.

521 Osono, T., Ishii, Y., Takeda, H., Seramethakun, T., Khamyong, S., To-Anun, C., Hirose, D., Tokumasu, S., and Kakishima, M. 2009. Fungal succession and lignin decomposition on Shorea obtusa leaves in a tropical seasonal forest in northern Thailand. Fungal Div. 36: 101-119.

525 Osono, T., To-Anun, C., Hagiwara, Y., and Hirose, D. 2011. Decomposition of wood, petiole, and leaf litter by Xylaria species from northern Thailand. Fungal Ecol. 4: 210-218.

528 Osono, T., Tateno, O., and Masuya, H. 2013. Diversity and ubiquity of 
529

530

531

532

533

535

536

538

539

540

541

542 enzymatically amplified ribosomal DNA from several Cryptococcus xylariaceous endophytes in live and dead leaves of temperate forest trees. Mycoscience 54: 54-61.Tamura, K., Stecher, G., Peterson, D., Filipski, A., Kumar, S., 2013. MEGA6: molecular evolutionary genetics analysis version 6.0. Mol. Biol. Evol. 30: 2725-2729.

Tian, X., Takeda, H., and Azuma, J.I. 2000. Dynamics of organic-chemical components in leaf litters during a 3.5-year decomposition. Eur. J. Soil Biol. 36: 81-89.

Van der Wal, A., Geydan, T.D., Kuyper, T.W., and de Boer, W. 2013. A thready affair: linking fungal diversity and community dynamics to terrestrial decomposition processes. FEMS Microbiol. Rev. 37: 477-494.

Van Maanen, A., Debouzie, D., and Gourbière, F. 2000. Distribution of three fungi colonizing fallen Pinus sylvestris needles along altitudinal transects. Mycol. Res. 104: 1133-1138.

Vilgalys, R., and Hester, M. 1990. Rapid genetic identification and mapping of species. J. Bacteriol. 172: 4238-4246. 
$546 \quad$ Figure legend

548 Fig. 1. Bleached area (\% total leaf area or length) on leaves of subboreal and

549 subalpine forests of different elevations (a) and as related to $\mathrm{C} / \mathrm{N}$ ratio of $\mathrm{FH}$

550 layer in subboreal forests (b). Values are means $(n=10)$ and bars indicate

551 standard errors. Numbers indicate the elevations. Gray columns and open

552 squares, Betula ermanii; blank columns and filled circles, Quercus crispula;

553 striped columns, Picea jezoensis var. hondoensis.

554

555 Fig. 2. Maximum-likelihood (ML) phylogeny inferred from 28S rDNA partial

556 sequences including 41 bleaching fungi isolated from bleached and nonbleached

557 portions of leaf litter in subboreal and subalpine forests. The evolutionary model

558 used was the Kimura 2-parameter model (Kimura 1980) with a discrete Gamma

559 distribution $(+\mathrm{G}$, parameter $=0.5624)$. Bootstrap values for the $\mathrm{ML}$ analysis are

560 indicated for corresponding branches. GenBank accession numbers are given in 
561 parentheses.

562 
Fig. 1
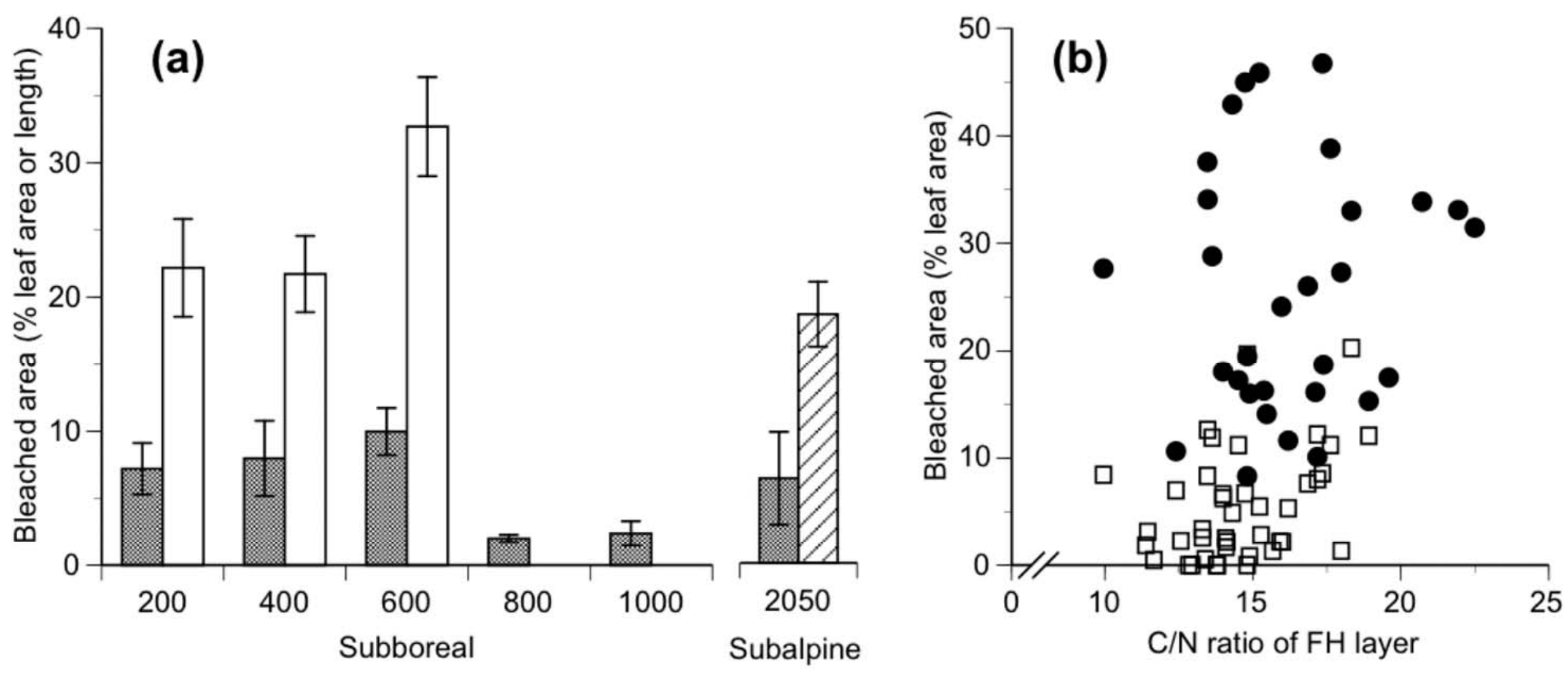
Fig. 2

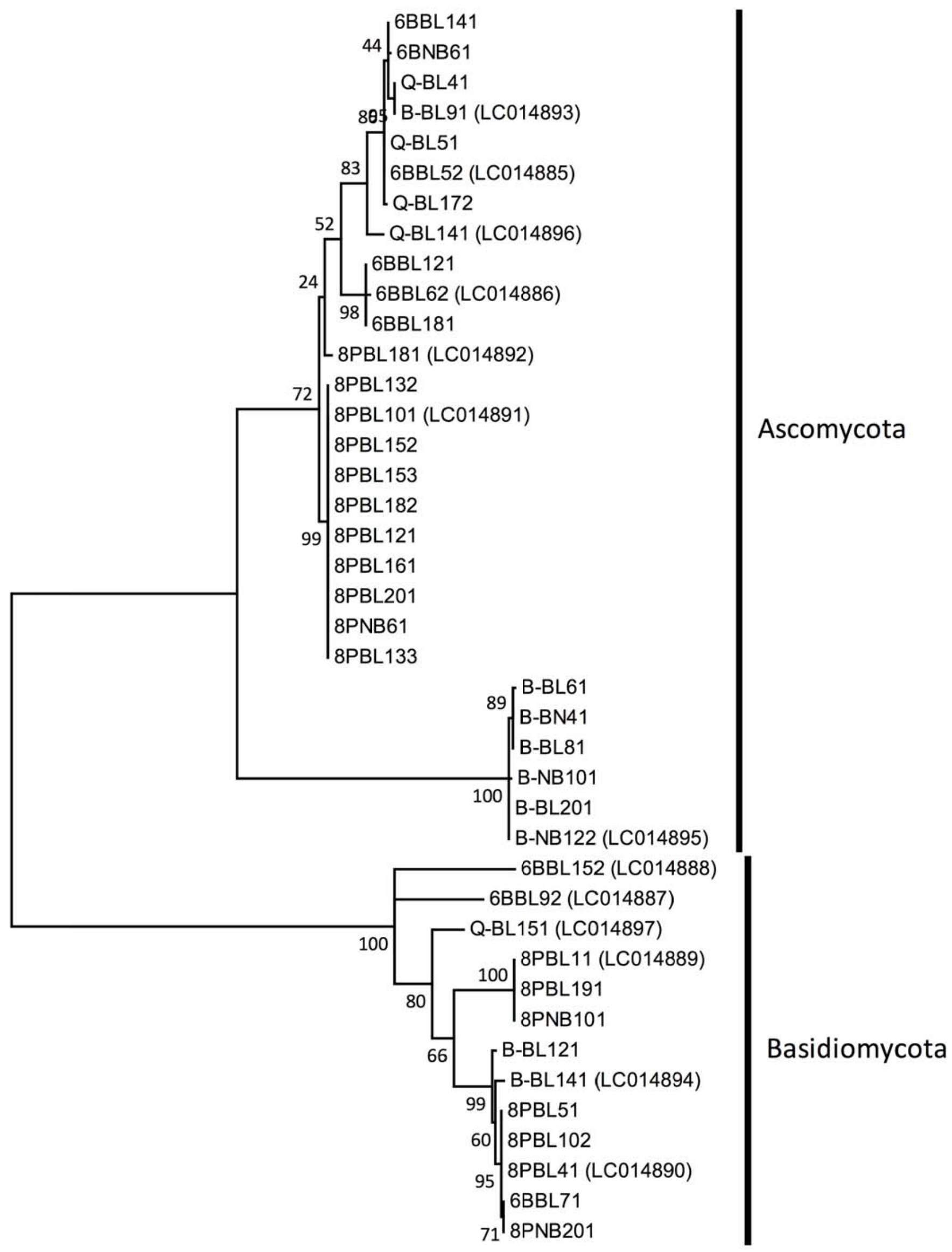


1 Hagiwara et al. Table 1.

2

3

4

5 Table 1. Summary of generalized linear models for bleached leaf area in subboreal forests

6 and selected predictor variables. ns, not selected. *** $\mathrm{P}<0.001,{ }^{*} \mathrm{P}<0.05$. The water content

7 of FH layer and the inclination of the slope were not selected as predictor variables

\begin{tabular}{lllll}
\hline & \multirow{2}{*}{$\begin{array}{l}\text { Quercus crispula } \\
\end{array}$} & & \multicolumn{2}{c}{ Betula ermanii } \\
\cline { 5 - 5 } & Deviance & Probability & Deviance & Probability \\
\hline Elevational class & 772.0 & $0.02^{*}$ & 463.7 & $<0.001^{* * *}$ \\
C/N ratio of FH layer & 436.3 & $0.04^{*}$ & 47.3 & 0.08 \\
pH of FH layer & 120.4 & 0.28 & $\mathrm{~ns}$ & \\
Slope aspect & $\mathrm{ns}$ & & 31.1 & 0.16 \\
\hline
\end{tabular}

8 
$9 \quad$ Hagiwara et al. Table 2

Table 2. Leaf mass per area (LMA, $\left.\mathrm{mg} / \mathrm{cm}^{2}\right)$ and the content $(\mathrm{mg} / \mathrm{g})$ of acid unhydrolyzable residue (AUR) in bleached (BL) and 14 nonbleached (NB) portions of leaf litter from subboreal and subalpine forests. Values indicate means \pm standard errors

$15(\mathrm{n}=4-10)$. nd, no data. na, not analyzed because of insufficient amount of samples for analysis.

\begin{tabular}{|c|c|c|c|c|c|}
\hline \multicolumn{4}{|c|}{ Subboreal } & \multirow{2}{*}{\multicolumn{2}{|c|}{$\begin{array}{l}\text { Subalpine } \\
\text { Betula ermanii }\end{array}$}} \\
\hline \multicolumn{2}{|c|}{ Quercus crispula } & \multicolumn{2}{|c|}{ Betula ermanii } & & \\
\hline $\mathrm{BL}$ & NB & BL & NB & BL & NB \\
\hline
\end{tabular}

\section{LMA in elevational class}

$200 \mathrm{~m}$

$400 \mathrm{~m}$

$600 \mathrm{~m}$

$800 \mathrm{~m}$

$1000 \mathrm{~m}$

$2050 \mathrm{~m}$

\section{Chemical content}

$\begin{array}{rr}5.3 \pm 0.3 & 7.4 \pm 0.4 \\ 4.4 \pm 0.3 & 6.4 \pm 0.3 \\ 4.1 \pm 0.3 & 6.1 \pm 0.3 \\ \text { nd } & \text { nd } \\ \text { nd } & \text { nd } \\ \text { nd } & \text { nd }\end{array}$

nd nd

nd nd

nd nd

nd nd

nd nd

$4.4 \pm 0.1 \quad 5.3 \pm 0.1$


17 Table 3. Number of isolates of bleaching fungi isolated from bleached and nonbleached portions of leaf litter and their

18 bleaching activity (as \% bleached leaf area caused by fungal isolates, with respect to total leaf area).

\begin{tabular}{|c|c|c|c|c|c|c|}
\hline \multirow[b]{2}{*}{ Fungus } & \multicolumn{2}{|c|}{ Subboreal } & \multicolumn{2}{|c|}{ Subalpine } & \multirow{2}{*}{$\begin{array}{l}\text { Total number } \\
\text { of isolates }\end{array}$} & \multirow{2}{*}{$\begin{array}{l}\text { Bleaching activity } \\
\text { Mean (min-max) }\end{array}$} \\
\hline & Quercus & Betula & Betula & Picea & & \\
\hline
\end{tabular}

\section{Ascomycota}

Coccomyces sp.

Rhytismataceae sp. 1

Xylariaceae sp.

Rhytismataceae sp.2

Rhytismataceae sp.3

Lophodermium sp.

1
0
6
0
0
0
0

\section{Basidiomycota}

Mycena sp.

Clitocybe sp.

Peniophora sp.

Ceriporia sp.

Tricholomatacea sp.

Number of species

$\begin{array}{lll}0 & 2 & 1 \\ 1 & 0 & 0 \\ 0 & 0 & 1 \\ 0 & 0 & 1 \\ 0 & 0 & 0 \\ 3 & 3 & 5\end{array}$

10

0
0
0
0
10
1

$61(10-90)$

90

$7(0-10)$

$63(50-90)$

53 (30-90)

50

19 